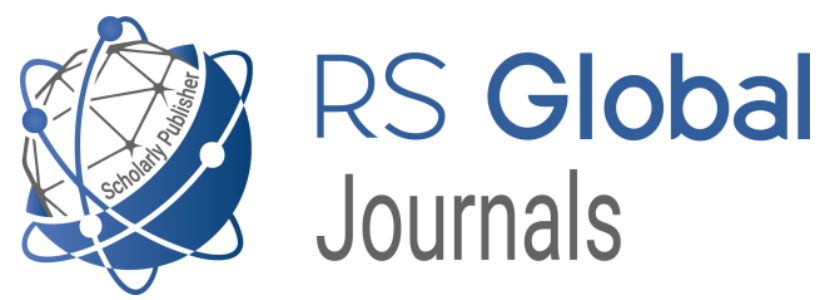

Scholarly Publisher RS Global Sp. z O.O. ISNI: 0000000484952390

Dolna 17, Warsaw, Poland 00-773

Tel: +48 226022703

Email: editorial_office@rsglobal.pl

\begin{tabular}{ll} 
JOURNAL & Science Review \\
\hline p-ISSN & $2544-9346$ \\
\hline e-ISSN & $2544-9443$ \\
\hline PUBLISHER & RS Global Sp. z O.O., Poland
\end{tabular}

$\begin{array}{ll}\text { ARTICLE TITLE } & \text { ТЕХНОЛОГІЧНІ ТА ЕКОЛОГІЧНІ АСПЕКТИ } \\ \text { ОТРИМАННЯ ПОВЕРХНЕВО-АКТИВНИХ РЕЧОВИН }\end{array}$
AUTHOR(S)
О. В. Османова

ARTICLE INFO

Osmanova O. V. (2020) Technological and Ecological Aspects

\begin{tabular}{|c|c|}
\hline ARTICLE INFO & $\begin{array}{l}\text { of Surfactants Production. Science Review. 8(35). } \\
\text { doi: } 10.31435 / \text { rsglobal_sr/30122020/7298 }\end{array}$ \\
\hline DOI & https://doi.org/10.31435/rsglobal_sr/30122020/7298 \\
\hline RECEIVED & 10 October 2020 \\
\hline ACCEPTED & 26 November 2020 \\
\hline PUBLISHED & 01 December 2020 \\
\hline \multirow[b]{2}{*}{ LICENSE } & (c) $\underset{\mathrm{EY}}{(\mathbf{7}}$ \\
\hline & $\begin{array}{l}\text { This work is licensed under a Creative Commons Attribution } \\
\text { 4.0 International License. }\end{array}$ \\
\hline
\end{tabular}

(C) The author(s) 2020. This publication is an open access article. 


\title{
ТЕХНОЛОГІЧНІ ТА ЕКОЛОГІЧНІ АСПЕКТИ ОТРИМАННЯ ПОВЕРХНЕВО-АКТИВНИХ РЕЧОВИН
}

\author{
О. В. Османова, кафедра Безпека прациі та навколиинього середовища , Національний \\ технічний університет «Харківський політехнічний інститут», Харків, Украӥна, \\ ORCID ID: https://orcid.org/0000-0002-2572-5900
}

DOI: https://doi.org/10.31435/rsglobal_sr/30122020/7298

\section{ARTICLE INFO}

Received 10 October 2020

Accepted 26 November 2020

Published 01 December 2020

\section{KEYWORDS}

surfactants,

enzymatic esterification, lipase,

non-aqueous medium,

sugar fatty acid esters.

\begin{abstract}
Surfactants are used in various industries: in foods, pharmaceuticals, textiles, personal care products, detergents, polymers, paints and coatings, etc. Scientific researches of technological and ecological aspects of surfactants (sugars fatty acids esters) production are carried out. Traditionally, sugars fatty acids esters are synthesized by chemical methods (using high temperature and pressure, in the presence of basic or acid catalysts and organic solvents). Replacing chemical catalysts with enzymes is an example of "green" production. Various approaches to the use of a non-aqueous medium for biocatalytic esterification are reviews. The most ecological approach is determined - esterification in a solvent-free environment, which ensures improved enzyme activity retention, the absence of costs associated with solvent usage and recovery, facilitates further product purification, reduces the impact on the environment, increases safety in the workplace.
\end{abstract}

Citation: Osmanova O. V. (2020) Technological and Ecological Aspects of Surfactants Production. Science Review. 8(35).doi: 10.31435/rsglobal_sr/30122020/7298

Copyright: (C) 2020 Osmanova O. V. This is an open-access article distributed under the terms of the Creative Commons Attribution License (CC BY). The use, distribution or reproduction in other forums is permitted, provided the original author(s) or licensor are credited and that the original publication in this journal is cited, in accordance with accepted academic practice. No use, distribution or reproduction is permitted which does not comply with these terms.

Вступ. Поверхнево-активні речовини - хімічні продукти, що споживаються у великій кількості у світовому масштабі. Поверхнево-активні речовини використовуються в різних галузях промисловості: в харчовій, фармацевтичній, текстильній, у виробництві засобів особистої гігієни, миючих засобів, полімерів, фарб та покриттів та інші. На відміну від мила та миючих засобів, виготовлених до початку XX століття, більшість 3 яких виготовлялися 3 тваринних жирів або рослинних олій, поверхнево-активні речовини, вироблені протягом останніх ста років, все більше залежать від нафти.

3 тих пір, як стало відомо, що поверхнево-активні речовини можуть несприятливо впливати на водне довкілля, здатність ПАР до біологічного розкладання та біологічна сумісність стали такими ж важливими для споживача, як і їх функціональні властивості [1-2].

Останнім часом у екологів та науковців викликає стурбованість довгострокова екологічна стійкість ПАР на основі викопних видів палива, що призводить до відновлення інтересу до біологічної сировини. Джерелом біологічної сировини, який найчастіше використовується для виготовлення поверхнево-активних речовин, $є$ жирна ацильна група, отримана 3 рослинних олій. Гідрофільна частина поверхнево-активних речовин також може бути отримана з поновлюваних джерел, таких як цукри, гліцерин, амінокислоти та їх похідні.

Мета роботи. Проведення аналітичного огляду способів отримання поверхневоактивних речовин - складних ефірів жирних кислот й цукрів. Визначення найбільш екологічного й технологічно обгрунтованого підходу для отримання жирнокислотних ефірів цукрів. 
Аналіз основних досягнень і літератури. Поверхнево-активні речовини традиційно виготовляють за допомогою хімічних процесів, які споживають велику кількість енергії, наприклад, при температурах, що перевищують $100^{\circ} \mathrm{C}$, вимагають високої кислотності або лужності реакційного середовища або використання органічних розчинників. Заміна хімічних процесів на ферментні, є прикладом "зеленого виробництва".

Використання ферментних каталізаторів має ряд переваг у порівнянні з хімічними:

-знижується температура процесів, (більш низьке енергоспоживання, що призводить до зниження викидів $\mathrm{CO}_{2}$ та інших парникових газів в навколишнє середовище),

-зменшується кількість відходів виробництва та побічних продуктів, відсутні токсичні металічні каталізатори, кислоти та луги (підвищується безпека на робочому місці та у навколишньому середовищі).

Більш низькі температури знижують небажані побічні реакції, такі як деградація подвійних зв'язків у ненасичених ацильних групах. Заміна металевих, кислотних або лужних каталізаторів на ферментні зменшує викид важких металів і інших потенційно шкідливих речовин у навколишне середовище, а також їх вміст у кінцевому продукті. Крім того, через високу селективність біокаталізаторів розподіл продуктів часто звужується порівняно 3 хімічними синтезами. При використанні стехіометричних пропорцій субстратів у ферментативних процесах зменшується кількість невикористаних субстратів у кінцевому продукті, таким чином зменшується навантаження для очищення [3].

До недоліків ферментного отримання поверхнево-активних речовин можна віднести наступні: висока вартість ферментів, низька швидкість реакції, необхідність використання високо очищених вихідних матеріалів, обмеження операційних умов, а саме температурного інтервалу та значення $\mathrm{pH}$. Ці недоліки стримують сучасне використання ферментних процесів, оскільки вони вимагають попередніх процесів очищення та створюють обмеження робочих умов (температура нижче $100^{\circ} \mathrm{C}$, щоб уникнути денатурації ферментів). Нові досягнення в галузі ензимології, такі як розробка технології іммобілізації ферментів, отримання більш активних та стабільних ферментних препаратів дозволяють збільшити термін їх використання i зробити ферментативні технології більш привабливими і перспективними [3].

Ефіри цукрів та жирних кислот виробляються з відновлюваних ресурсів, таких як цукри та жирні кислоти. Вони біологічно розкладаються, не мають запаху, не токсичні, не викликають подразнення, знайдено їх широке застосування в харчовій, косметичній та фармацевтичній галузях. Складні ефіри цукрів та жирних кислот можуть бути синтезовані шляхом етерифікації жирними кислотами або переетерифікації з карбоновими ефірами у неводних середовищах для запобігання можливого гідролізу ефірного продукту.

Традиційно ефіри цукрів й жирних кислот синтезуються хімічними методами в екстремальних умовах (з застосуванням високої температури й тиску, у присутності лужних або кислотних каталізаторів [4-5]. Так, синтез складних ефірів сорбітану та жирних кислот включає двостадійний процес, що складається 3 дегідратації сорбітану в присутності $\mathrm{NaH}_{2} \mathrm{PO}_{3}$ при 150$200{ }^{\circ} \mathrm{C}$, а потім в присутності каталізатора карбонату натрію етерифікація жирними кислотами при $200-250{ }^{\circ} \mathrm{C}$ [6]. Ефіри сахарози синтезують у присутності каталізатора карбонату калію переетерифікацією з метиловим ефіром жирної кислоти в диметилформаміді при $90{ }^{\circ} \mathrm{C}$ [6-7].

Для отримання ефірів цукрів й жирних кислот з використанням ферментних препаратів в лабораторному масштабі у неводних середовищах автори застосовували органічні розчинники, надкритичний діоксин вуглецю, іонні рідини, евтектичні суміші та середовища, що не містять розчинників. Ферменти каталізують реакції в неводному середовищі за м'яких умов, дозволяють отримати вузький розподіл продуктів при порівняно високих швидкостях реакції [8]. Розчинники зазвичай використовують для ферментного синтезу ефірів цукрів й жирних кислот у лабораторних масштабах, щоб допомогти солюбілізувати реакційну суміш. Тип розчинника чинить різний вплив на ферментну реакцію. В літературі багато прикладів порівняння використання різних типів розчинників (ацетон, діоксан, 2-метил-2-бутанол, етилметилкетон, тетрагідрофуран, ацетонітріл, гептан, толуол та інші) та джерел ліполітичних ферментів для оптимізації швидкості реакції та виходу ефірів [9-17].

Синтез моно- та діефірів трегалози каприлової, лауринової та пальмітинової кислот каталізували ліпазою Fermase CALB тм 10000. Активність ферменту сильно залежить від природи розчинника. Більшість ферментів демонструють кращу стабільність у неполярних 
розчинниках а отже, і високу активність. Однак неполярні розчинники не є кращим реакційним середовищем для етерифікації через низьку розчинність полярних сполук, таких як дисахариди. Отже, відповідний розчинник дав би кращий вихід цукрового ефіру, демонструючи кращу розчинність дисахариду та / або демонструючи кращу стабільність ферменту. Оскільки етерифікація є реакцією дегідратації, реакційне середовище для опосередкованого ліпазою синтезу ефірів жирних кислот має бути неводним. Ідеальним розчинником для синтезу ефірів цукрових жирних кислот буде той, який показує максимальну розчинність обох реагентів і не перешкоджає активності ферментів. Серед досліджуваних розчинників лише ацетон показав перетворення трегалози в складні ефіри жирних кислот. Жоден з інших розчинників не виявив ніякої етерифікації. Синтез моно- та діефірів трегалози був успішно проведений в ацетоні 3 використанням дигідрату трегалози та пальмітинової кислоти. Оптимізоване молярне перетворення $35 \%$ трегалози в ії складні ефіри пальмітату було отримано в ацетоні при $60{ }^{\circ} \mathrm{C} 3$ молярним співвідношенням трегалоза: пальмітинова кислота 1: 5 за 4 год. [18].

Дві імобілізовані ліпази з Candida antarctica (SP 382) і C. Cylindracea були використані для синтезу нових ацетильованих ефірів жирних кислот та глюкози з пентаацетатом глюкози та рослинним маслом ( $80 \%$ олеїну) як субстратами в органічних розчинниках. Відносний вихід продуктів реакції склав 6,4-52\%, а включення олеїнової кислоти в глюкозу становила 31$100 \%$. Крім того, ці два фермента змогли каталізувати синтез складних ефірів жирних кислот і глюкози з вільною глюкозою як субстратом. [19].

Walsh M.К. порівнював різні ліпази (з Pseudomonas cepacia, R. miehei, Candida antarctica i Thermomyces lanuginosus) та розчинники (2-метил-2-бутанол, ацетон і метилетилкетон) у ферментному синтезі монолаурату лактози та монолаурату сахарози. Оптимальні умови синтезу спостерігались при використанні 2-метил-2-бутанолу та ліпази R. miehei (Lipozyme IM, Novozymes) при $61^{\circ} \mathrm{C}$, при початковому мольному співвідношенню вініллаурат : лактоза 3,8:1, 3 виходом $99,3 \%$ [9].

B роботі Sabeder S. M. та ін. досліджено вплив органічних розчинників (2-метил-2бутанола, третбутанола, ацетона, метилетилкетона) на синтез пальмітату фруктози. Ступінь перетворення $82 \%$ було отримано для метилетилкетона за 72 години при $40{ }^{\circ} \mathrm{C}$ з використанням $10 \%$ массових молекулярних сит для видалення реакційної води. Іммобілізовані препарати ліпази Candida antarctica B (SP 435 та SP 382 від Novozymes) успішно каталізували етерифікацію фруктози та пальмітинової кислоти з отриманням 53 \% та 44 \% пальмітату фруктози в 2-метил-2бутанолі при $40^{\circ} \mathrm{C}$, швидкості перемішування 600 об/хв 3 додаванням молекулярних сит [20]. Ефіри лактози жирних кислот були ферментативно синтезовані з жирних кислот та лактози 3 використанням ліпази Candida antarctica B (CALB) в органічних розчинниках. Результати показали, що гексан та ацетонітрил забезпечують найвищі показники перетворення як вільних, так і іммобілізованих ліпаз, до 77\% та 93\% відповідно. Швидкість перетворення етерифікації залежить від розчинника для вільної ліпази; ступінь перетворення іммобілізованої ліпази демонструє залежність від розчинника, але в меншій мірі [21].

Висока активність ферментів та стабільність досягається при використанні неполярних розчинників, які також придатні для ферментної переетерифікації олій та жирів [22], однак розчинність цукрів у них дуже низька. Існує обмежена кількість органічних розчинників, що можуть бути ефективно використані для синтезу складних ефірів цукрів та жирних кислот: трет-бутанол, трет-пентанол, ацетон і тетрагідрофуран. Більш полярні розчинники, незважаючи на їх здатність солюбілізувати цукри, працюють погано, оскільки призводять до втрати ферментної активності завдяки здатності видаляти молекули води 3 мікросередовища ферменту, та сприяють гідролізу ефірних продуктів i утворенню побічних продуктів, зменшують вихід цільового продукту [23-24]. Окрім поліпшення солюбілізації і відсутності інактивації ферменту, ідеальне органічне середовище повинно бути екологічно чистим і легко відновлюватися і перероблятися після завершення реакції [25-26]. Серед розчинників середньої полярності, які найкраще підходять для ферментної етерифікації цукрів жирними кислотами, ацетон найбільш відповідає умовам ідеального розчинника [27]. Корисними для синтезу були системи розчинників, що поєднують два або більше органічних розчинників. Бінарна система розчинників 2-метил-2 бутанол: диметилсульфоксид (4:1) була використана для етерифікації глюкози, сахарози та мальтози в присутності ліпази з Candida antarctica i Thermomyces lanuginosus шляхом поєднання невеликої частки розчинника, що значно покращує 
солюбілізацію ефірів (диметилсульфоксид) 3 більшою часткою розчинника, що дозволяє зберегти високу активність ферментів, але погано солюбілізує акцептор ацилу (2-метил-2бутанол). За допомогою такого підходу вихід монолаурату сахарози становить більше $80 \%$ [28]. Хоча використання органічних розчинників у ферментному синтезі має певне значення, існує декілька недоліків для їх широкомасштабного впровадження у промисловому синтезі, такі як втрата активності ферментів, яку вони часто спричиняють, турбота про вплив на екологію та особисту безпеку. Таким чином, необхідно вести пошуки альтернативних підходів.

Інший підхід, винайдений для ферментного синтезу складних ефірів цукрів та жирних кислот, полягає у використанні переважно твердофазної системи, що складається 3 цукрів, жирної кислоти та продукту реакції у присутності невеликої кількості органічного розчинника, наприклад, трет-бутанолу або ацетону [29]. Порівняно з реакціями в середовищі органічного розчинника початкова швидкість реакції та загальна продуктивність реакції в твердій фазі часто вища в кілька разів [11]. Успіх такого підходу можна пояснити твердофазною підкладкою, що діє як «резервуар» для поповнення рідкофазного субстрату, що перетворюється у продукт. Крім того, осадження продукту спрощує подальше очищення продукту і може посилити вибірковість продукту. Наприклад, моноефір сахарози та жирної кислоти, утворений у твердофазному середовищі, легко випадає в осад, зменшуючи здатність ліпази каталізувати утворення диефірів. Евтектична суміш, що складається з твердої та рідкої фази, забезпечує спосіб, при якому зменшується температура плавлення суміші. Органічний розчинник зазвичай зменшує температуру плавлення, що призводить до евтектичної суміші при кімнатній температурі або нижче [29]. Евтектична суміш містить переважно молекули субстрату і невелику кількість органічного розчинника. Евтектичні середовища демонструють стабільну біокаталітичну рідку фазу 3 надзвичайно високою концентрацією субстратів. Найнижча температура плавлення називається евтектичною точкою, яку можна визначити за певним складом суміші. Завдяки використанню невеликої кількості органічних розчинників у евтектичному середовищі, їх можна вважати більш біосумісними та сприятливими для ферментних реакцій, ніж у чистому органічному розчиннику [30-31]. В результаті ацилювання $\beta$-D-глюкози пальмітиновою кислотою у трет-бутанолі у присутності ліпази 3 Candida antarctica В у твердофазній системі був синтезований ефір 3 високою селективністю (98\% моноацилювання). Селективність в ацилюванні суттєво пов'язані з типом органічного розчинника. Моноацилювання відбувалось в присутності менш гідрофобного розчинника, наприклад, трет-бутанолу [32]. Хоча синтез ефірів жирних кислот в твердофазній системі демонструє високу швидкість реакції, кількісний вихід ефірів цукрів та жирних кислот, високу селективність реакції, він $є$ реакцією на основі органічних розчинників, що веде до збільшення вартості процесу та негативно позначається на безперервності процесу.

Надкритичний вуглекислий газ - привабливе альтернативне середовище для синтезу ефірів цукрів і жирних кислот. Він має ряд переваг у порівнянні з органічними розчинниками як реакційне середовище через відсутність токсичності, негорючість порівняно 3 традиційними підходами хімічного синтезу. Робочий стан: температура більше $31^{\circ} \mathrm{C}$, тиск більш 7,3 МПа. Потужність розчинника надкритичного $\mathrm{CO}_{2}$ контролюється за допомогою регулювання температури та тиску. Простий процес відновлення продуктів і частинок ферментного препарату 3 реакції представляє додаткову перевагу [33]. Експерименти демонструють задовільну стабільність ферментів у надкритичному $\mathrm{CO}_{2}$ у порівнянні зі стабільністю ферментів в органічних розчинниках [34]. Створено пристрій з перемішуванням для етерифікації фруктози пальмітиновою кислотою 3 каталізатором ліпазою Candida antarctica В (Новозим 435) в надкритичному діоксиді вуглецю. Було отримано ступінь перетворення $60 \%$ при $60^{\circ} \mathrm{C}$ та $10 \mathrm{MПа} \mathrm{за} 24$ години [35]. Хоча надкритичний вуглекислий газ $є$ корисною та перспективною заміною органічних розчинників у синтезі складних ефірів цукрів та жирних кислот, існують два основних недоліки, які необхідно подолати при використанні такого реакційного середовища: низька розчинність неполярних сполук та великі капітальні затрати та експлуатаційні витрати [36].

Іонні рідини, що складаються 3 органічних солей, які знаходяться в рідкій фазі при температурі навколишнього середовища, представляють унікальний клас неводних та полярних середовищ розчинників, що привертають все більше уваги в органічному синтезі через відсутність тиску парів та відмінну хімічну та термічну стабільність [36-38]. Через низькі температури плавлення та нелетучу природу іонні рідини , які називаються «зеленими» розчинниками, $є$ привабливою альтернативою летким органічним розчинникам [39]. Крім того, 
їх широко регульовані властивості щодо полярності, гідрофобності, характеру змішуваності можна змінити, вибравши хімічну структуру їх катіонних та аніонних фрагментів [40]. Для більшості неводних досліджень в ензимології відносно неполярні іонні рідини, такі як 1-бутил3-метил імідазолій гексафторфосфат або 1-бутил-3-метил імідазолій тетрафторборат ([Bmim][PF6], [Bmim][BF4] відповідно) можуть бути використані як замінники органічних розчинників. Було досліджено, що ліпаза В Candida antarctica та термолізін не виявляють різниці в стабільності та селективності в іонних рідинах порівняно 3 гексаном, тетрагідрофураном та ацетонітрілом у біокаталітичних реакціях $[38,41]$. Було виявлено, що ліпаза B Candida antarctica, модифікована ковалентним приєднанням поліетиленгліколю, каталізувала етерифікацію глюкози та жирних кислот у чистому [Bmim][BF4] та [Bmim][PF6] зі ступенем перетворення $30 \%$ та $35 \%$ відповідно. Хоча ступінь перетворення $30 \%$ та $35 \% \epsilon$ низьким, додавання трет-бутанолу до іонних рідин з утворенням двофазної системи, збільшило ступінь перетворення до 89 \% [42]. Селективний каталізований ліпазою синтез ефірів глюкози жирних кислот у двофазних системах, що складаються 3 іонної рідини (1-бутил-3метилімідазолій тетрафторборат [BMIM] [BF4] або 1-бутил-3-метил імідазолій гексафторфосфат [BMIM] [PF6]) та т-бутанол як органічний розчинник. Найкращим ферментом була комерційно доступна ліпаза В з Candida antarctica. Після ретельної оптимізації кількох умов реакції (довжина ланцюга та тип донора ацилу, температура, час реакції, відсоток співрозчинника) можна досягти перетворень до $60 \%$, використовуючи вініловий ефір жирних кислот як донорів ацилу в [BMIM] [PF6] у присутності $40 \%$ t-BuOH з CAL-B при $60^{\circ} \mathrm{C}$ [24]. Lee S.H. та співавтори досліджували етерифікацію перенасиченого розчину D-глюкози в іонних рідинах, що каталізується ліпазою. Отримано вихід моноефіру (6-О-лауроїл- D-глюкози) 96 \%. Високу початкову швидкість у [Bmim] [TfO] було досягнуто при застосуванні перенасиченого розчину глюкози у іонній рідині. Ці результати вказують на корисність перенасичених розчинів для ферментної етерифікації цукрів з жирними кислотами [43].

Реакційне середовище, що не містить розчинника, бажано для синтезу складних ефірів цукрів та жирних кислот, що каталізуються ліпазою завдяки низькій вартості, підвищеній безпеці експлуатації та покращеній біосумісності для застосування в харчовій, косметичній, фармацевтичній галузях [44-45].

Ефіри цукрів та жирних кислот були синтезовані при молярному співвідношенні ацильної групи жирних кислот до акцептора ацилу цукру 1:1 та 2:1 при зниженому тиску для видалення побічних продуктів (води або метанолу, що утворюються при використанні вільної жирної кислоти або метилового ефіру жирної кислоти як донора ацилу відповідно) [46]. Складні ефіри технічного класу олеїнової кислоти та сахарози та фруктози були синтезовані біокаталітично без розчинника при $65^{\circ} \mathrm{C}$ без подальшого очищення. Для збільшення ступеня перетворення олеату сахарози та фруктози, отриманого раніше біокаталітичною етерифікацією без розчинника у присутності ліпази Rhizomucor miehei (з виходом $81 \%$ та 83 \% відповідно), умови ферментативної реакції продовжували у присутності сульфату кальцію і ліпази В Candida antarctica 3 гідрофобною матрицею для забезпечення низької водної активності, та 3 гомогенізацією під високим тиском для утворення метастабільної суспензії сахаридних частинок розміром 2,0-3,3 мкм у рідкофазному реакційному середовищі. Це призвело до збільшення вмісту складних ефірів сахарози і фруктози до $89 \%$ та $96 \%$ відповідно. Це дослідження демонструє важливість контролю активності води біокаталізаторів для досягнення високого ступеня перетворення [47].

Для застосування посиленої змішуваності в синтезі ефірних продуктів цукрів D.G. Hayes та його колеги розробили системи біореакторів для етерифікації жирних кислот та цукрів, каталізованих ліпазою у середовищі без розчинників при температурі $65{ }^{\circ} \mathrm{C}$ [48-49]. Високий вихід (85\%) був досягнутий при використанні біореактора 3 упакованим шаром 3 безперервною рециркуляцією.

Висновки. Розробка нових екологічно чистих поверхнево-активних речовин залишається актуальним питанням. Отримання складних ефірів жирних кислот й цукрів біокаталітичною етерифікацією за допомогою ліпаз призводить до зменшення споживання розчинників, зниження температури та зниження відходів. Більш екологічний підхід у середовищі без використання розчинника забезпечує збереження активності ферментів, мінімальні вимоги до подальшого очищення, відсутність витрат, пов’язаних з використанням та відновленням розчинника. 


\section{REFERENCES}

1. Infante, M.R., Perez L., Pinazo A. (2004), “Amino acid-based surfactants”, Comptes Rendus Chimie. 7, 583-592.

2. Clapés, P., Infante, M. R. (2002), “Amino Acid-based Surfactants: Enzymatic Synthesis, Properties and Potential Applications", Biocatalysis and Biotransformation, 20 (4), 215-233.

3. Hayes D. G. (2012), "Using enzymes to prepare biobased surfactants". Retrieved from https://www.aocs.org/stay-informed/inform-magazine/featured-articles/using-enzymes-to-preparebiobased-surfactants-july/august-2012

4. Feuge, R.O., Zerinque, H.J., Weiss, T.J., Brown, M. (1970), "Preparation of Sucrose Esters by Interesterification", Journal of the American Oil Chemists Society, 47 (2), 56-60.

5. Cauglia, F., Canepa, P. (2008), "The enzymatic synthesis of glucosylmyristate as a reaction model for general considerations on 'sugar esters' production", Bioresource Technology, 99 (10), 4065-4072.

6. Hill, K., Rhode O. (1999), "Sugar-based surfactants for consumer products and technical applications", Fett-Lipid, 101 (1), 25-33.

7. Polat, T. and Linhardt R.J. (2001), "Synthesis and applications of sucrose-based esters", Journal of Surfactants and Detergents, 4, 415-421.

8. Lee, M.Y. and. Dordick, J.S. (2002), "Enzyme activation for nonaqueous media", Current Opinion in Biotechnology, 13 (4), 376-384.

9. Walsh, M.K., et al. (2009), "Synthesis of lactose monolaurate as influenced by various lipases and solvents", Journal of Molecular Catalysis B-Enzymatic, 60 (3- 4), 171-177.

10. Arcos, J.A., Bernabe, M., Otero, C. (1998), "Quantitative enzymatic production of 6- O-acylglucose esters", Biotechnology and Bioengineering, 57 (5), 505- 509.

11. Cao, L.Q., et al. (1997), "Lipase-catalyzed solid phase synthesis of sugar fatty acid esters", Biocatalysis and Biotransformation, 14 (4), 269-283.

12. Khaled, N., et al. (1991), "Fructose Oleate Synthesis in a Fixed Catalyst Bed Reactor", Biotechnology Letters, 13(3), 167-172

13. Ward, O.P., Fang, J.W., Li, Z.Y. (1997), "Lipase-catalyzed synthesis of a sugar ester containing arachidonic acid", Enzyme and Microbial Technology, 20 (1), 52-56.

14. Oguntimein, G.B., Erdmann, H., Schmid, R.D. (1993), "Lipase Catalyzed Synthesis of Sugar Ester in Organic-Solvents", Biotechnology Letters, 15 (2), 175- 180.

15. Yadav, G.D. and Lathi, P.S. (2005), "Lipase catalyzed transesterification of methyl acetoacetate with nbutanol", Journal of Molecular Catalysis B-Enzymatic, 32 (3), 107-113.

16. Xiaoming, Z., et al. (2002), "Lipase-catalyzed synthesis of 6-O-vinylacetyl glucose in acetonitrile", Biotechnology Letters, 24 (13), 1097- 1100.

17. Ren, K., Lamsal, B. P. (2017), "Synthesis of some glucose-fatty acid esters by lipase from Candida Antarctica and their emulsion functions", Food Chemistry, 214(1), 556-563.

18. Marathe, S.J., Shah, N.N., Singhal, R.S. (2020), "Enzymatic synthesis of fatty acid esters of trehalose: Process optimization, characterization of the esters and evaluation of their bioactivities", Bioorganic Chemistry, 94, 103460.

19. Akoh, C.C. (1994), "Enzymatic synthesis of acetylated glucose fatty acid esters in organic solvent", Journal of the American Oil Chemists' Society, 71, 319-323.

20. Sabeder, S., Habulin, M., Knez, Z. (2006), "Lipase-catalyzed synthesis of fatty acid fructose esters", Journal of Food Engineering, 77(4), 880-886.

21. Yijing, M., Gong, Y., Goddard, J.M., Abbaspourrad, F. (2018), "Synthesis and characterization of lactose fatty acid ester biosurfactants using free and immobilized lipases in organic solvents", Food Chemistry, 266 (15), 508-513.

22. Carrea, G., Ottolina, G., Riva, S. (1995), "Role of Solvents in the Control of Enzyme Selectivity in Organic Media", Trends in Biotechnology, 13 (2), 63-70.

23. Hayes, D.G. (2004), "Enzyme-catalyzed modification of oilseed materials to produce eco-friendly products", Journal of the American Oil Chemists Society, 81 (12), 1077-1103.

24. Ganske, F., Bornscheuer, U.T. (2005), "Optimization of lipase-catalyzed glucose fatty acid ester synthesis in a two-phase system containing ionic liquids and t-BuOH", Journal of Molecular Catalysis B-Enzymatic, $36(1-6), 40-42$.

25. Villeneuve, P. (2007), "Lipases in lipophilization reactions", Biotechnology Advances, 25 (6), 515-536.

26. Chang, S.W., Shaw, J.F. (2009), "Biocatalysis for the production of carbohydrate esters", New Biotechnology, 26 (3-4), 109-116.

27. Degn, P. and Zimmermann, W. (2001), "Optimization of carbohydrate fatty acid ester synthesis in organic media by a lipase from Candida Antarctica”, Biotechnology and Bioengineering, 74 (6), 483-491.

28. Ferrer, M., et al. (2005), "Synthesis of sugar esters in solvent mixtures by lipases from Thermomyces lanuginosus and Candida antarctica B, and their antimicrobial properties”, Enzyme and Microbial Technology, 36 (4), 391-398.

29. Gill, I., Vulfson, E. (1994), "Enzymatic Catalysis in Heterogeneous Eutectic Mixtures of Substrates", Trends in Biotechnology, 12 (4), 118-122. 
30. Gill, I., Vulfson, E.N. (1993), "Enzymatic-Synthesis of Short Peptides in Heterogeneous Mixtures of Substrates", Journal of the American Chemical Society, 115 (8), 3348-3349.

31. Cao, L.Q., Bornscheuer, U.T., Schmid, R.D. (1996), "Lipase-catalyzed solid phase synthesis of sugar esters", Fett-Lipid, 98 (10), 332-335.

32. Cao, L.Q., Bornscheuer, U.T., Schmid, R.D. (1999), "Lipase-catalyzed solid-phase synthesis of sugar esters. Influence of immobilization on productivity and stability of the enzyme", Journal of Molecular Catalysis B-Enzymatic, 6 (3), 279-285.

33. Sabeder, S., Habulin, M., Knez, Z. (2005), "Comparison of the esterification of fructose and palmitic acid in organic solvent and in supercritical carbon dioxide", Industrial \& Engineering Chemistry Research, 44 (25), 9631- 9635.

34. Tai, H.P., Brunner, G. (2009), "Sugar fatty acid ester synthesis in high-pressure acetone-CO2 system", Journal of Supercritical Fluids, 48 (1), 36-40.

35. Tsitsimpikou, C., et al. (1998), "Acylation of glucose catalysed by lipases in supercritical carbon dioxide", Journal of Chemical Technology and Biotechnology, 71 (4), 309-314.

36. Kragl, U., Eckstein, M., Kaftzik, N. (2002), "Enzyme catalysis in ionic liquids", Current Opinion in Biotechnology, 13 (6), 565-571.

37. van Rantwijk, F., Lau, R.M., Sheldon, R.A. (2003), "Biocatalytic transformations in ionic liquids", Trends in Biotechnology, 21 (3), 131-138.

38. Park, S., Kazlauskas, R.J. (2003), "Biocatalysis in ionic liquids - advantages beyond green technology", Current Opinion in Biotechnology, 14 (4), 432-437.

39. Sureshkumar, M., Lee, C.K. (2009), "Biocatalytic reactions in hydrophobic ionic liquids", Journal of Molecular Catalysis B-Enzymatic, 60 (1-2), 1-12.

40. Gangu, S.A., Weatherley, L.R., Scurto, A.M. (2009), "Whole-Cell Biocatalysis with Ionic Liquids", Current Organic Chemistry, 13 (13), 1242-1258.

41. Kaar., J.L. (2003), "Impact of Ionic Liquid Physical Properties on Lipase Activity and Stability". Journal of the American Chemical Society, 125 (14), 4125- 4131.

42. Ganske, F. Bornscheuer, U.T. (2005), "Lipase-catalyzed glucose fatty acid ester synthesis in ionic liquids", Organic Letters, 7 (14), 3097-3098.

43. Ye, Ran (2011), "Bioreactor system design for lipase-catalized synthesis of saccharide-fatty acid esters in solvent-free media".

44. Foresti, M.L., et al. (2007), "Multiple effects of water on solvent-free enzymatic esterifications", Enzyme and Microbial Technology. 41 (1-2). 62-70.

45. Ogawa, S., Endo, A., Kitahara, N., et al. (2019), "Factors determining the reaction temperature of the solvent-free enzymatic synthesis of trehalose esters", Carbohydrate Research, 482 (8), 107-139.

46. Fregapane, G., Sarney, D.B., Vulfson, E.N. (1991), "Enzymatic Solvent-Free Synthesis of Sugar Acetal Fatty-Acid Esters”, Enzyme and Microbial Technology, 13 (10). 796-800.

47. Ye, Ran, Hayes, D.G., Burton, R., Liu, A. (2016), "Solvent-Free Lipase-Catalyzed Synthesis of Technical-Grade Sugar Esters and Evaluation of Their Physicochemical and Bioactive Properties", Catalysts, 6 (6), 78-82.

48. Pyo, S.H., Hayes, D.G. (2008), "Desorption of Fructose from a Packed Column to an Oleic Acid/Fructose Oleate Mixture for Employment in a Bioreactor System", Journal of the American Oil Chemists Society, 85 (11), 1033-1040.

49. Pyo, S.H., Hayes, D.G. (2009), "Designs of Bioreactor Systems for Solvent-Free Lipase-Catalyzed Synthesis of Fructose-Oleic Acid Esters", Journal of the American Oil Chemists Society, 86 (6), 521-529. 